\title{
Internal Control System Quality and Decision-Making Success: The Role of the Financial Information Quality
}

\author{
Albertina Paula Moreira Monteiro, ${ }^{1, *}$, Joana Andreia Machado Vale ${ }^{2}$, \\ Catarina Libório Morais Cepêda ${ }^{2}$, Eduardo Manuel de Almeida Leite ${ }^{3}$ \\ ${ }^{1}$ Porto Accounting and Business School, Polytechnic of Porto, CEOS.PP, Porto, Portugal \\ ${ }^{2}$ Porto Accounting and Business School, Polytechnic of Porto, Porto, Portugal \\ ${ }^{3}$ Higher School of Technology and Management, University of Madeira, CiTUR, Portugal
}

Received February 24, 2021; Revised April 22, 2021; Accepted May 16, 2021

\section{Cite This Paper in the following Citation Styles}

(a): [1] Albertina Paula Moreira Monteiro, Joana Andreia Machado Vale, Catarina Libório Morais Cepêda, Eduardo Manuel de Almeida Leite, "Internal Control System Quality and Decision-Making Success: The Role of the Financial Information Quality," Universal Journal of Accounting and Finance, Vol. 9, No. 3, pp. 285 - 294, 2021. DOI: 10.13189/ujaf.2021.090302.

(b): Albertina Paula Moreira Monteiro, Joana Andreia Machado Vale, Catarina Libório Morais Cepêda, Eduardo Manuel de Almeida Leite (2021). Internal Control System Quality and Decision-Making Success: The Role of the Financial Information Quality. Universal Journal of Accounting and Finance, 9(3), 285 - 294. DOI: 10.13189/ujaf.2021.090302.

Copyright $\odot 2021$ by authors, all rights reserved. Authors agree that this article remains permanently open access under the terms of the Creative Commons Attribution License 4.0 International License

\begin{abstract}
This study aims to develop and evaluate a Decision-Making Success contingency model to assess its dependency on Internal Control System Quality and Financial Information Quality. The authors developed a study based on a sample of 381 Portuguese managers. The structural equations model was used in the analysis of causal relationships between different constructs. Results show that Internal Control System Quality contributes directly to Decision-Making Success. Moreover, Internal Control System Quality and Financial Information Quality are determining factors for Decision-Making Success since Internal Control System Quality has a significant direct impact on Financial Information Quality (with a 64\% coefficient of determination) and indirect on DecisionMaking Success. The model justifies $67 \%$ of the variance of the dependent variable. This research covers a literature gap, since it identifies innovatively, two independent variables that are determinant for Decision-Making Success from the Portuguese companies' manager perspective. This study is relevant to literature development, as it develops and evaluates an original model, and to managers, in the sense that it identifies factors that contribute to Portuguese companies' success.
\end{abstract}

Keywords Contingency Theory, Decision-Making Success, Financial Information Quality, Internal Control
System Quality

\section{Introduction}

With the progress of economic activity, accounting has been an essential tool to support management in decisionmaking [1].

Therefore, accounting information is an important resource in the decision-making process. Akhtar and Liu [2] (p. 390) indicate that the accounting information "should be used by the external and internal evaluators of the company, to guide better decisions". Thus, the literature suggests that accounting is a vital tool in the management of an entity and decisive for decision-making [3]. However, decision-makers need useful and quality accounting information to support their decisions $[4,5]$. Hence, a highquality decision needs high-quality information [6].

According to Fitriati and Susanto [4], the accounting information system quality and the quality of financial reports influence the Decision-Making Success. Thus, accounting information system allows the obtaining, registering, saving, and processing of data to provide useful financial information to decision-makers [7]. However, the 
accounting information system quality is dependent on the Internal Control Quality [8]. On the other hand, the literature suggests that accounting information system quality is a predictive variable of Financial Information Quality [9-15]. In addition, existing studies indicate that the quality of the accounting information system and the internal control system have a positive impact on DecisionMaking Success $[4,16]$. However, in the literature there are no studies that test the effect of Internal Control System Quality on Financial Information Quality, as well as its impact on Decision-Making Success.

Given successful decision-making can determine the survival and growth of companies, a better understanding of factors that influence business success is necessary. Considering the above, this study aims to analyze whether the Internal Control System Quality influences the Financial Information Quality and whether these have an impact on Success in Decision-Making.This investigation is based on contingency theory, which recognizes that each company has its characteristics and that the manager's decisions are influenced by different company characteristics [17]. This research perspective is centered on a positivist epistemological basis, which uses a quantitative methodology. The quantitative approach is based on a survey of Portuguese company managers.

This research focused on 381 Portuguese companies, suggests 'first-hand' that Internal Control Systems improve the Financial Information Quality and this, in turn, contributes positively to the success of decision-making. Because it evaluates an original model, this study proves to be relevant not only for the development of the literature but also for managers, in the sense that it identifies the factors that contribute to the success of decision-making. Understanding the determinants of business success is important for Portuguese companies as the bankruptcy rate is significant in Portugal.

This paper structure is as follows: the next section introduces the main topics related to empirical research and presents investigation hypotheses. The following sections develop procedures and samples used to test the research hypotheses. In the penultimate and last section, empirical findings are discussed, and research conclusions and their implications are presented.

\section{Literature Review and Hypotheses Development}

Managers are decision-makers and their decisions can lead to the company's success or failure [18]. According to Lugli and Bertacchini [19], in modern organisations, decision-making processes are increasingly managed by systems of rules to reduce the risks in business management. The decision-making process, in the organizational environment, is characterized by logical thinking conducted by a person with legitimate decision power where through the help of expert's parts, seeks to prepare, manage, implement, and control a certain decision [20]. For Harren [21] the decision-making model is a description of a psychological process in which the decision-maker, based on information, evaluates the different alternatives to solve the problem and commits to an action. However, there are three types of decision-making: sporadic (subject to major disruption, and with a great opportunity for negotiation); fluid (faster, flows into formal meetings with fewer impediments and delays); and restricted (flows less than the fluid process and occurs more often than sporadic, tending to circle a central figure) [22]. According to the same authors, the main decision factor is the duality of complexity and political burden, which together determine the kind of process that strategic decisions follow.

In the area of decision implementation, Nutt [23] sustains that decisions can take place in various ways, such as intervention, participation, persuasion, and order, the first being the most effective. Besides the way decisions can be implemented, they can vary in content (what the decision is about); in the process (how the decision moves through the organizations), and in importance (operational or strategic) [24].

Decision-makers need the information to support their choices, that is, information of a qualitative and quantitative nature [25]. This author mentions that the largest amount of data, in real-time, can help decisionmakers to make the best choices.

Therefore, to make an effective decision, the decisionmaker must recognize and assess the problems, process all essential information, select the best strategy and finally make a decision [26].

Decision-making is a complex process, which makes it difficult to manage problems and make decisions successfully $[27,28])$. The Decision-Making Success is a valuable strategic outcome of implementing Internal Control System Quality and the usefulness of financial information [29]. However, one of the important assumptions in the decision-making process is the existence of quality and timely financial information, so the accounting information system represents an important tool both for information quality and in the decision-making process [16].

The decision-making process should include procedures that ensure the achievement of corporate objectives effectively and efficiently and contribute positively to organization performance [15]. Literature suggests that Decision-Making Success and organization performance depend on several factors, which supports the contingency theory. According to contingency theory, a company's success "depends on the fit between organizational context and structure" [30] (p. 837). For this applied theoretical lens, there is no universal method for a company to succeed because each company will depend on and conform to its various economic, social, and physical environments [26].

Decision-making is subject to contingencies that vary 
according to the business environment in which the company operates [30]. Thus, any company and any type of business are always dependent on numerous internal and external factors that will be fundamental to a good organization's performance [31]. According to contingency theory, organizational effectiveness depends on a fit between the type of technology, environmental volatility, the organization size and structure, and its information system [32].

Within the information system, literature is focused on Internal Control Quality and Financial Information Quality as they play an important role in organizations due to their strong impact on their performance [7]. Given that decision-making depends to a large extent on financial information, the more useful the information is in the decision-making process, the greater its contribution to Successful Decision-Making [25].

According to Tarter and Hoy's [31] study, the proposed contingency theory for decision-making has practical usefulness, as Decision-Making Success depends on the Internal Control System and the Financial Information Quality.

Internal control is a valuable mechanism for all companies, without which the companies' goals cannot be achieved effectively and efficiently [55]. Internal control is an activity that involves financial and management accounting, strategic projects, operational and personnel management, as well as total quality management [33]. Internal control measures, which cover all aspects of accounting, can contribute to the effectiveness of accounting and labour management [34].

According to Rashedi and Dargahi [35] (p. 33), the internal control system provides internal accounting controls, which covers "organizational structure, methods and measures are coordinated primarily to keep the organization's wealth and check the accuracy and reliability of accounting data". For Rashedi and Dargahi [35] (p. 33), "control objectives are to keep information systems function maintaining information confidentiality". Internal control systems play an important role in prevention, risk discovery and contribute to Financial Information Quality [36]. However, according to the American Institute of Certified Public Accountants (AICPA) [37], internal control systems mainly allow minimizing the risk of unintentional errors or intentional fraud.

For the growth and survival of companies it is important to maintain quality standards of the Internal Control System. as it allows them to control and analyze the veracity of companies' results [29]. Literature suggests that managers of companies with an internal control system make better decisions [7, 38]. Empirical evidence is also verified in Ibrahim et al.'s [39] study. Thus, the existing literature proves that maintaining the quality levels of the Internal Control System can influence the growth of companies, because it facilitates the planning and control of their activities and, consequently, the decision-making process.

According to International Auditing Standards, the internal control system should be the basis of each company's development plan, which should help it to properly organize and control all its activity [33]. However, for effective control, the internal control system must ensure the efficiency of the company's operations, compliance with financial and operational indicators, the safety of assets, and the credibility of financial reporting, as well as compliance with the law [36].

In Phornlaphatrachakorn's [29] study, Internal Control System Quality had a positive effect on the DecisionMaking Success of the companies under study (canned and processed foods businesses in Thailand). On the other hand, Feng et al. [40] (p. 207) show that weak internal control “affect managers' decisions related to production, capital investment, mergers and acquisitions, research and development, advertising, and hiring or expansion decisions". Thus, the improvement of the internal control system can effectively improve the efficiency of decisionmaking and therefore determine its success [41]. Literature suggests that the Internal Control System Quality is a determinant of Decision-Making Success, however, there is no empirical evidence for companies from various industries. To cover the literature gap, this study, based on a sample of Portuguese companies from various industries (e.g., service, industry and commerce), aims to test the following research hypothesis.

H1: Internal Control System Quality has a positive impact on Decision-Making Success.

Fitriati and Susanto's [4] (p. 5003) study suggests that the implementation of "a qualified accounting information system" improves accounting information quality. Based on a sample of higher education institutions, these authors analyze the dependence of the quality of the accounting information system on internal control and top management support and the impact of the quality of the accounting information system on the quality of accounting information. Thus, previous research suggests that Accounting Information System Quality and Internal Control System Quality are predictive variables of the quality of financial information [11, 12, 13, 29, 35, 42].

Gal and Akisik's [12] results show that market value is positively influenced by internal control systems and quality of integrated reports. Frazer [11] states that to promote accurate financial reporting, the control must be efficiently applied in company. Rashedi and Dargahi [35], found that the quality of financial reporting is affected by the accounting information system and the internal control system.

Accordingly, Internal Control System Quality can contribute to success in any company by promoting accurate financial reporting, through increased Financial Information Quality [11, 12, 13, 14, 29, 35] and operational efficiency [11, 42]. Thus, companies with weak Internal Control Quality tend to present financial information with 
lower quality [29] and therefore contributes to a decline in stakeholder confidence in financial statements [5]. Other authors, such as Sajady et al. [38], highlight that accounting information systems enhance the quality of financial reports and that implementation of accounting information systems at these companies caused the improvement of internal controls. Thus, we expect the Internal Control System Quality to contribute positively to Financial Information Quality. In this context, we formulate the second research hypothesis:

H2: Internal Control System Quality has a positive impact on Financial Information Quality.

Accounting, as a science, is concerned with the preparation, analysis, and disclosure of information [45]. Eierle and Schultze [46] mention that, according to the frameworks of the International Accounting Standards Board (IASB) and Financial Accounting Standards Board (FASB), the main objective of financial statements is to provide useful information to existing or potential investors and other company stakeholders. Information, to be useful, must comply with quality requirements as the usefulness of financial information is associated with Financial Information Quality [16].

Thus, financial information should gather qualitative characteristics to become useful in decision-making [48]. In this sense, the accounting must obey all the qualitative characteristics of the Financial Statements, specifically, they must respect their intelligibility, this is, consider the relevance of financial information, as well as their comprehensibility, reliability, and comparability [47].

Managers should be aware that financial information, when analyzed, can help keep their financial situation under control and, consequently, enhance business growth [39]. Financial statements are the stakeholders' main source of information and are important in the decisionmaking process [24]. However, Srivastava and Lognathan [48], state that financial information is only effective if it largely serves the needs of internal and external stakeholders.

Decision-makers need information to support their choices, that is, information of both qualitative and quantitative nature [25]. This author mentions that information usefulness, in real-time, can help the decisionmakers formulate the best choices.

Ježovita [49] and Dewi et al. [50] study, concluded that relevant financial information in financial reporting is crucial for the decision-making process. Thus, decisionmaking based on financial information provided by accounting, and bringing together all its qualitative characteristics, can determine the Decision-Making Success. In the same sense, Malo-Alain, Melegy, and Ghoneim [51] state, based on literature review, that absence of Financial Information Quality may jeopardize DecisionMaking Success. In this context, we formulate the third hypothesis:

H3: Financial Information Quality has a positive impact on Decision-Making Success.

\section{Theoretical Model and Methodology of the Study}

Based on contingency theory, this research aims to analyze the relationship between Internal Control System Quality and Decision-Making Success and the mediating impact of the Financial Information Quality. The conceptual model is presented in figure 1 .

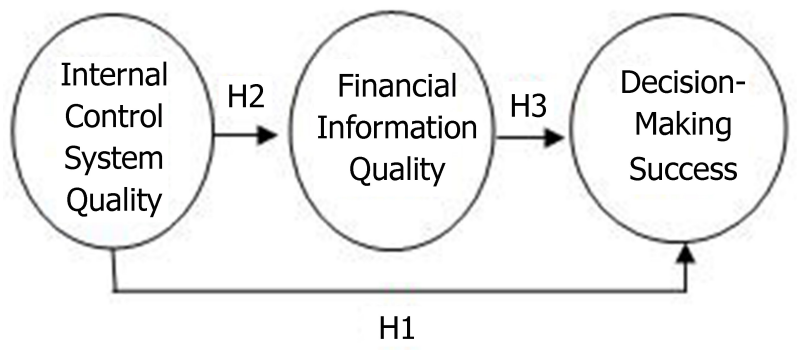

Figure 1. Research model

To achieve the proposed objective, this study is based on a quantitative approach, which involves the application of a survey addressed to managers of Portuguese companies. The survey was developed in the Lime Survey software. This measuring instrument was subject to a pre-test.

The survey structure is divided into 4 parts. The first part includes questions to characterize the sample. The remaining parts include items that allow evaluating the dimensions under study (Internal Quality System Quality, Financial Information Quality, and Decision-Making Success). This research uses validated/adapted measurement scales from previous studies and the ordering of responses, for each item of the constructs shown in the proposed conceptual model, follows Likert's 5-point scale, where 1 corresponds to "totally disagree" and 5 corresponds to "totally agree". Multi-item measurement is a scientific instrument of observation and measurement of social phenomena attitudes through opinions in an objective way [52]. Methodologists and scholars in psychometrics have raised issues regarding subjectivity and the number of items considered necessary to form a scale of individuals' perceptions, however, both the Likert scale and multi-item scales are widely used and represent useful means for researchers seeking information about individuals' perceptions [53].

We measured Internal Control System Quality and Decision-Making Success using Phornlaphatrachakorn's [29] measurement scale. The Measurement scale of Financial Information Quality was adopted/adapted from Dornier's [54] study.

The sampling selection process was performed in the SABI database, applying the following 5 filters: (1) all companies with an e-mail address in Portugal; (2) the last number of employees: minimum 50; (3) companies with 
auditing; (4) companies with the legal form: sole proprietorship, foreign entity, joint-stock company, limited liability company and sole proprietorship; and (5) active companies.

The SABI database generated a list of 7,812 Portuguese companies. Despite the substantial number of companies, it was decided to apply the survey to all companies instead of limiting the study to one region or district of the country. This option is foreseen as this study is applied to company managers and there is a likelihood of obtaining a reduced response rate.

The survey was applied online, the link to it was sent by email to the companies-and addressed to the person who makes companies' main decisions (managers). In the period from 2 to 31 March 2020 emails were sent (total 7799 emails). During the period mentioned, 389 complete observations were obtained. Given the high number of Portuguese companies, a non-probabilistic sample was chosen, which is practical in scientific studies covering a very large population $[55,56]$.

The data analysis comprises three phases: (1) preliminary data analysis, (2) measurement model evaluation, and (3) structural model evaluation.

All data "cleaning" procedures were performed in the SPSS software, which involves 4 steps: (1) treatment of missing data, (2) extreme data analysis (outliers), (3) analysis of central tendency and normality, and (4) sample size analysis. After duly prepared, statistical data analysis was performed using the Structural Equations Model in the SPSS Software Amos, since it is a valuable technique in data analysis when the objective is to test the hypotheses formulated in the research [57] and the theoretical model includes complex relationships and variables/dimensions that are not measured directly, but through their indicators or items [57].

\section{Results}

\subsection{Sample Characteristics}

Regarding the distribution of companies by district, 111 (29.1\%) companies are located in the Lisbon district, 67 (17.6\%) in Oporto, and $41(10.8 \%)$ in the Aveiro district. These 3 districts represent $57.5 \%$ of the sample. Therefore, $42.5 \%$ of the companies are distributed in other 14 districts or autonomous regions. As to the typology, 197 (52\%) are public limited companies, 121 (32\%) private limited companies 17 (4\%) single partner limited companies. However, 46 respondents selected the "Others" option, which represents $12 \%$.

In respect to the sector of activity, 160 (42\%) companies have as object the rendering of services, $126(33 \%)$ and 43 (14\%) companies develop industrial and commercial activities, respectively, and $42(11 \%)$ of the respondents selected the option "Other", to indicate that they develop functions in companies related to tourism (1), insurance (1), construction (2), floriculture (1), transport of goods (1) and banking and insurance (1).

As the Accounting of the company is assured in the company, $250(65.6 \%)$ surveyed mention that they hold the service within the company itself, and $69(18.1 \%)$ mention that they subcontract the accounting service. However, 62 $(16.3 \%)$ of the companies mention that they have both services, that is, that they have a department internally, but still subcontract the service externally. Regarding the internal control service, $267(70.1 \%)$ of the respondents mention that they have the service internally and $31(8.1 \%)$ fully subcontract the service. However, 77 (20.2\%) say they have both and only $6(1.6 \%)$ say they have no internal control in the entity.

\subsection{Structural Equation Model}

We performed a preliminary data analysis to prepare the data for the SEM analysis. The preliminary data analysis focused on the analysis of missing values, outliers, sample size, central tendencies and normality of the data.

SEM analysis involves two steps: (1) the evaluation of the measurement model, and (2) the evaluation of the structural model.

\subsection{Measurement Model Assessment}

In the analysis of the measurement model, we used confirmatory factor analysis to validate the measurement scales used in the assessment of each construct of the conceptual model. The maximum likelihood estimation method was used in this process. This method is considered reliable because it uses covariance matrices. [59] and it is most widely in most statistical packages, such as in AMOS [60]. According to Diamantopoulos and Siguaw [61], this method is robust against moderate violations of assumptions of normality [62], as is in this study.

The evaluation of measurement model results is illustrated in Table 1. We verify that all items report significantly to each factor, which confirms the unidimensionality of the measurement scale used to assess each construct. The values of the average variance extracted $(>0.50)$ and standardized coefficients $(>0.60)$ demonstrate the existence of discriminant and convergent validity of the measurement scales, respectively $[63,64]$. The values of composite reliability $(>0.60)$ prove the reliability of the measurement scale [65].

\subsubsection{Structural model assessment}

To test the proposed hypotheses in the research model, we estimated the structural model. Adjustment indicators show a good fit of the model $\left(\chi^{2}=93,75(46), \mathrm{p}=0.00, \mathrm{CFI}=\right.$ $0.99, \mathrm{GFI}=0.96, \mathrm{NFI}=0.97, \mathrm{RMSEA}=0.049)$. Table 2 presents the evaluation results of the structural model.

Results indicate that Internal Control System Quality has 
a positive and significant effect on Decision-Making Success $(\beta=.20 ; \mathrm{p}$-value<.001), which allows us to conclude that the improvement of Internal Control System Quality contributes to the improvement of DecisionMaking Success, which corroborates previous studies [29, 40, 41]. In this study, the H1 is supported.

Results prove also that Internal Control System Quality has a positive and significant effect on Financial Information Quality $(\beta=.80$; $\mathrm{p}$-value<.001), which allows us to conclude that the improvement of Internal Control System Quality contributes to the improvement of
Financial Information Quality and that the first variable explains $64 \%$ of the second. Our results support the $\mathrm{H} 2$ and they are in accordance with previous studies $[8,10,19,38$, 44].

As expected, the results of this research indicate that Decision-Making Success is also influenced by Financial Information Quality $(\beta=.65$; $\mathrm{p}$-value<.001), which allows us to conclude that the improvement of Financial Information Quality is determinants to Decision-Making Success, meeting the Malo-Alain, Melegy, and Ghoneim's [51] results. The results allow us to support $\mathrm{H} 3$.

Table 1. Measurement model results

\begin{tabular}{|c|c|}
\hline Construct & Sc \\
\hline \multicolumn{2}{|l|}{ Internal Control System Quality $(\mathrm{CR}=.94, \mathrm{AVE}=.69)$} \\
\hline The internal control system has improved and promoted the company's operational efficiency and effectiveness. & $.805^{*}$ \\
\hline Internal control system has allowed building and creating effective operations, activity, and business practices. & $.737 *$ \\
\hline The internal control system has allowed the company to prepare IFs with quality. & $.900 *$ \\
\hline $\begin{array}{l}\text { The company complies with all required regulations, i.e., laws, rules, guidelines, standards, and other issues } \\
\text { related to internal control. }\end{array}$ & $.881^{*}$ \\
\hline \multicolumn{2}{|l|}{ Financial Information Quality $(\mathrm{CR}=.90, \mathrm{AVE}=.57)$} \\
\hline The accuracy of financial information helps decision-making. & $.693^{*}$ \\
\hline Financial information is carefully prepared to ensure its reliability. & $.804 *$ \\
\hline Financial information is easily understood by its user. & $.753^{*}$ \\
\hline The financial information represents in a reliable way what you want to portray. & $.763^{*}$ \\
\hline \multicolumn{2}{|l|}{ Decision-Making Success $(\mathrm{CR}=.95, \mathrm{AVE}=.72)$} \\
\hline $\begin{array}{l}\text { The decisions made allowed the company to achieve advantages in terms of operations, management, and } \\
\text { performance. }\end{array}$ & $.853^{*}$ \\
\hline $\begin{array}{l}\text { The decisions made about investments considered different alternatives or options, which allowed the company } \\
\text { to choose the best solution. }\end{array}$ & $.857 *$ \\
\hline The decisions made have contributed to maximize efficiency and increase operational effectiveness. & $.907 *$ \\
\hline The decisions made in the company determine its success. & $.776^{*}$ \\
\hline
\end{tabular}

Table 2. Research model results

\begin{tabular}{|cc|c|c|c|}
\hline \multicolumn{2}{|c|}{ Parameters } & Standardized coefficient & $p$-value & $\mathrm{R}^{2}$ \\
\hline ICSQ - & FIQ & .80 & $* * *$ & .64 \\
\hline FIQ - & DMS & .65 & $* * *$ & .67 \\
\hline ICSQ - & .20 & $* * *$ & \\
\hline $\begin{array}{l}\text { Legend: ICSQ, Internal Control System Quality; FIQ, Financial Information Quality; DMS, Decision-Making Success; } \mathrm{R}^{2}, \text { coefficient of } \\
\text { determination. *** Correlation is significant at the 0.1\% level }\end{array}$ \\
\hline
\end{tabular}

Results show that independent variables (Internal Control Quality and Financial Information Quality) explain $67 \%$ of the dependent variable.

In addition, in this study, we verify that Internal Control Quality has an indirect impact on Decision-Making Success through Financial Information Quality $(\beta=.52$; $\mathrm{p}$ value $<.001$ ), with a total impact of .72 .

This study, anchored in the contingency theory, draws important conclusions, i.e., Decision-Making Success is strongly dependent on Internal Control System and
Financial Information Quality. Nevertheless, we prove that Financial Information Quality is an important mediating variable in the relationship between Financial Information Quality and Decision-Making Success.

\section{Conclusions}

In Portugal, around $99.9 \%$ of companies are Micro, Small, and Medium-Sized Enterprises. This highlights its 
importance to the Portuguese economy.

Since February 2018, the number of new companies is higher than the number of companies going into insolvency proceedings [66]. However, the number of bankruptcies remains significant. The data are very worrying and have an impact on the country's economic level of development, so it is crucial to study the determinants of business success

Literature then suggests the development of studies that aim to identify factors that contribute to the survival and growth of firms [13]. In this context, the main objective of this study is to analyze the factors (Internal Control System Quality, Financial Information Quality) that directly and indirectly influence Decision-Making Success.

Based on a sample of 381 Portuguese companies, it was possible to develop and evaluate a contingency model of Decision-Making Success to evaluate their dependency on Internal Control System Quality and Financial Information Quality.

Concerning the first hypothesis, results show that Internal Control System Quality has a positive and significant effect on Decision-Making Success. Results support $\mathrm{H} 1$ and they are in accordance with Phornlaphatrachakorn [29], Feng et al. [40], and Han's ([41]) studies.

Regarding the second hypothesis, we conclude that there is a positive and significant relationship between Internal Control System Quality and Financial Information Quality. Results support $\mathrm{H} 2$ and they reveal the important role of the internal control system in the transparency of financial reporting. These results corroborate with the fundamentals of Sajady et al. [38], Salehi et al. [8], Asare and Wright [44], Sari and Purwanegara [27] and Phornlaphatrachakorn [29].

Finally, the test for the last hypothesis of this study (H3) allows us to conclude that, like the Quality of Internal System Control, Financial Information Quality also has a positive and significant effect on Decision-Making Success, demonstrating that high-quality decision needs highquality information $[6,51]$.

Furthermore, results show that Internal Control System has an additional impact on Decision-Making Success if it contributes to an improvement to Financial Information Quality.

The literature review identified two gaps. The first relates to the absence of studies that analyze the determinants of Decision-Making Success through an integrated model that assesses the direct and indirect effect of Internal Control Quality on Successful Decision-Making. The second gap relates to the lack of studies in this area in Portugal. So, in practical terms, this research is important for Portuguese companies' managers, as it provides a better understanding of the factors that contribute positively to the Decision-Making Success of Portuguese companies.

Regarding study limitations, the use of a sample for convenience and non-probabilistic limits the generalization of results [67].

In terms of future research, we suggest that the usefulness of the financial information variable be added to the model since it is presented in the literature as a determining variable in Decision-Making Success [29]. Moreover, future research could add to the model the dependent variable organizational performance (in financial and non-financial terms) to evaluate the effects of independent variables. We also suggest that the study be applied to other countries in order to be able to compare results in similar contexts, despite differences inherent to each country.

\section{REFERENCES}

[1] Schwartz, M., "Ethical decision-making theory: An integrated approach", Journal of Business Ethics, vol.139, no.4, pp.755-776, 2016.

[2] Akhtar, S., and Liu, Y., 'SMEs' use of financial statements for decision making", Evidence from Pakistan. Journal of Applied Business Research, vol.34, no.2, pp.381-392, 2018, https://doi.org/10.1108/EJIM-12-2018-0269

[3] Florin, B., "Development of decision making by managers with financial and accounting information", Economic Sciences, vol.23, pp.40-56, 2014.

[4] Fitriati, A., Susanto, A., "The accounting information system qality improvement through internal control and top management support effectiveness" Journal of Theoretical and Applied Information Technology, vol.95, no.19, pp.5003-5011, 2017.

[5] Hall, James A., "Accounting Information System", 7th edition. Cengage Learning. South-Western, 2011.

[6] Laudon, K.C., J.P. Laudon, "Management Information System: Managing the Digital Firm", 12th Edn., PrenticeHall, New Jersey, USA., ISBN:9780132142854, Pages: 557, 2012.

[7] Nguyen, H. T., Nguyen, A. H., "Determinants of accounting information systems quality: Empirical evidence from Vietnam", Accounting, vol.6, no.2, pp.185-198, 2020, https://doi.org/10.5267/j.ac.2019.10.004

[8] Salehi, M., Rostami, V., Mogadam, A., "Usefulness of Accounting Information System in Emerging Economy: Empirical Evidence of Iran", International Journal of Economics and Finance, vol.2, no.2, pp.186-195, 2010.

[9] Bauer, A. M., Henderson, D., Lynch, D. P., "Supplier Internal Control Quality and the Duration of CustomerSupplier Relationships", The Accounting Review, vol.93, no.3, pp.59-82, 2017, https://doi.org/10.2308/accr51889

[10] Sari, N. Z. M., Afifah, N. N., Susanto, A., Sueb, M., "Quality Accounting Information Systems with 3 Important Factors in BUMN Bandung Indonesia”, Advances in Social Science, Education and Humanities Research, vol.343, no.1, pp.9396, 2019, https://doi.org/10.2991/icas-19.2019.20

[11] Frazer, L., "Does Internal Control Improve the Attestation Function and by Extension Assurance Services? A Practical 
Approach", Journal of Accounting and Finance, vol.20, no.1, pp.28-38, 2020, https://doi.org/10.33423/jaf.v20i1.27 39

[12] Gal, G., Akisik, O., "The impact of internal control, external assurance, and integrated reports on market value", Corporate Social Responsibility and Environmental Management, vol.27, no.3, pp.1227-1240, 2020, https://doi.org/10.1002/csr.1878

[13] Jokipii, A., "Determinants and consequences of internal control in firms: A contingency theory-based analysis", Journal of Management and Governance, vol.14, no.2, pp.115-144, 2010, https://doi.org/10.1007/s10997-0099085-x

[14] Li, C., Peters, G. F., Richardson, V. J., Watson, M. W., "The Consequences of Information Technology Control Weaknesses on Management Information Systems: The Case of Sarbanes-oxley Internal Control Reports", MIS Quarterly, vol.36, no.1, pp.179-203, 2012, https://doi.org/10.2307/41410413

[15] Soudani, S. N., "The Usefulness of an Accounting Information System for Effective Organizational Performance", International Journal of Economics and Finance, vol.4, no.5, pp.136-145, 2012, https://doi.org/10.5539/ijef.v4n5p136

[16] Patel, S. B. P., "Effects of accounting information system on organizational profitability", International Journal of Research and Analytical Reviews, vol.2, no.1, pp.72-76, 2015.

[17] Çaliyurt, K. T., "Importance of financial management knowledge in small and medium enterprises (smes) managing by women.Trakya", Üniversitesi Sosyal Bilimler Dergisi, vol.13, no.2, pp. 327-354, 2011.

[18] Cvetkoska, V., "A survey of the use of operational research in decisions made by micro, small and medium-sized enterprises in Macedonia”, Croatian Operational Research Review, vol.7, no.2, pp.349-365, 2016.

[19] Lugli, E., Bertacchini, F., "Can Practical Wisdom Mitigate the Negative Effects of Rule-following and Hypercodification," Universal Journal of Accounting and Finance, vol. 8, no. 3, pp. 75-81, 2020. DOI: 10.13189/ujaf.2020.080303.

[20] Gencia, A., Sandu, A., Puscas, A., Mates, D., "An international perspective upon the impact of financial statement form on the business decision making process", Lucrari Stiintifice, vol.18, no.1, pp.109-116, 2016.

[21] Harren, V. A., "A model of career decision making for college students", Journal of Vocational Behavior, vol. 14, no2, pp. 119-133, 1979. https://doi.org/10.1016/00018791(79)90065-4

[22] Cray, D., Mallory, G., Butler, R., Hickson, D., Wilson, D., "Sporadic, fluid and constricted processes: Three types of strategic decision-making in organizations", Journal of Management Studies, vol.25, no.1, pp.13-39, 2007, doi:10.1111/j.1467-64861988.tb00020.x

[23] Nutt, P. C., "Types of organizational decision processes", Administrative Science Quarterly, vol.29, no.3, pp.50-414, 1984.
[24] Menicucci, E., "Earnings Quality: Definitions, Measures, and Financial Reporting", Springer Nature, 2019, https://doi.org/10.2308/acch.2003.17.s-1.97.

[25] Smith, S. S., "Blockchain, artificial intelligence and financial services: Implications and applications for finance and accounting professionals", Springer, 2020, https://doi.org/10.1016/j.paid.2015.06.017

[26] Akdere, M., "An analysis of decision-making process in organizations", Implications for quality management and systematic practice", Total Quality Management, vol.22, no.12, pp. 1317-1330, 2011, https://doi.org/10.1080/14783 363.2011 .625180

[27] Powell, V., "Improving public enterprise performance: concepts and techniques", International Labour Organization, 1987, ISBN 9221055639, 9789221055631

[28] White, L. C., Pothos, E. M., Busemeyer, J. R., "Insights from quantum cognitive models for organizational decision making", Journal of Applied Research in Memory and Cognition, vol.4, no.3, pp.229-238, 2015, https://doi.org/10.1016/j.jarmac.2014.11.002

[29] Phornlaphatrachakorn, K., "Internal Control Quality, Accounting Information Usefulness, Regulation Compliance, and Decision- Making Success: Evidence from Canned and Processed Foods Businesses in Thailand", International Journal of Business, vol.24, no.2, pp.198-215, 2019.

[30] Cadez, S., Guilding, C., "An exploratory investigation of an integratedcontingency model of strategic management accounting", Accounting, Organisations and Society, vol.33, pp. 836-863, 2008, https://doi.org/10.1016/j.aos.2008.01.00

[31] Tarter, J. C., Hoy, W. K., "Toward a contingency theoryof decision making", Journal of Educational Administration, vol.36, no.3, pp. 212-228, 1998.

[32] Islam, J., Hu, H., "A review of literature on contingency theory in managerial accounting", African Journal of Business Management, vol.6, no.15, pp.5159-5164, 2012.

[33] Dimitrijevic, D., Milovanovic, V., Stancic, V., "The role of a company's internal control system in fraud prevention", e-Finanse, vol.11, no.3, pp.34-44, 2015,https://doi.org/10.1 4636/1734-039X

[34] Kuzmenko, H., Yahelska, K., Artyukh, O., Babich, I., Volenshchuk, N.,Sulimenko, L., "Improved Methodology of Accounting and Audit of Payments to Employees in Ukraine," Universal Journal of Accounting and Finance, Vol. 9, No. 1, pp. 44 -53, 2021. DOI: 10.13189/ujaf.2021.090105.

[35] Rashedi, H., Dargahi, T., "How Influence the Accounting Information Systems Quality of Internal Control on Financial Reporting Quality Hadi”, Journal of Modern Developments in Management and Accounting, vol.2, no.5, pp.33-45, 2019.

[36] Selezneva, E. Y., Rakutko, S. Y., Temchenko, O. S., "Optimize the Choice of Counteragent Based on the Application of the COSO Internal Control Model", In Advances in Economics, Business and Management Research, vol.128, pp.2291-2296 2020, https://doi.org/10.2991/aebmr.k.200312.316 
[37] AICPA, "The importance of internal controls in financial reporting and safeguarding plan assets", American institute of certified public accountant, 2014 https://doi.org/10.1093/petrology/44.4.603

[38] Sajady, H., Dastgir, M., Hashem Nejad, H., "Evaluation of the effectiveness of accounting information systems", International Journal of Information Science and Management, vol.6, no.2, pp.49-59, 2008.

[39] Ibrahim, F., Ali, D. N. H., Besar, N. S. A., "Accounting information systems (AIS) in SMEs", Towards an integrated framework. International Journal of Asian Business and Information Management, vol.11, no.2, pp.51-67, 2020.

[40] Feng, M., Li, C., McVay, S., "Internal control and management guidance", Journal of Accounting and Economics, vol.48 no.2-3, pp.190-209, 2009 https://doi.org/10.1016/j.jacceco.2009.09.004

[41] Han, X., "Internal control and non-efficiency investment of listed companies", International Social Sciences and Education Conference, vol.4, pp. 343-348, 2019, https://doi.org/10.25236/issec.2019.070

[42] Bozzolan, S., Miihkinen, A., "The quality of mandatory nonfinancial (risk) disclosures: the moderating role of audit firm and partner characteristics. Forthcoming", The International Journal of Accounting, Forthcoming, 2021, Available at SSRN: https://ssrn.com/abstract=3342703 or http://dx.doi.org/10.2139/ssrn.3342703.

[43] Baugh, M., Ege, M., Yust, C., "Internal control quality and bank risk-taking and performance", AUDITING: A Journal of Practice \& Theory, Forthcoming, 2020, https://papers.ssrn.com/sol3/papers.cfm?abstract_id=33029 36

[44] Asare, S. K., Wright, A., "The effect of type of internal control report on users' confidence in the accompanying financial statement audit report", Contemporary Accounting Research, vol.29, no.1, pp.152-175, 2012, https://doi.org/10.1111/j.1911-3846.2011.01080.x

[45] Elvisa, B., Ilgün, E., "Impact of Accounting Information Systems on Decision Making Case of Bosnia and Herzegovina", European Researcher, vol.96, no.7, pp.460 470, 2015, https://doi.org/10.13187/er.2015.96.460

[46] Eierle, B., Schultze, W., "The Role of Management as a User of Accounting Information: Implications for Standard Setting”, SSRN Electronic Journal, vol.12, no.2, pp.155-189, 2013, https://doi.org/10.2139/ssrn.1130162

[47] Christensen, J., "Conceptual frameworks of accounting from an information perspective", Accounting and Business Research, vol.40, no.3, pp. 287-299, 2010, https://doi.org/10.1080/00014788.2010.9663403

[48] Srivastava, P., Lognathan, M. S., "Impact of accounting information for management decision making", International Journal of Applied Research, vol.2, no.5, pp.171-174,2016.

[49] Ježovita, A., "Accounting information in a business decision-making process - evidence from Croatia", Zagreb International Review of Economics and Business, vol.18, no.1, pp.61-79, 2015, https://doi.org/10.1515/zireb-20150004

[50] Dewi, N. F., Ferdous Azam, S. M., Yusoff, S. K. M.,
"Factors influencing the information quality of local government financial statement and financial accountability", Management Science Letters, vol.9, pp.1373-1384, 2019. https://doi.org/10.5267/j.msl.2019.5.0 13

[51] Malo-Alain, A. M., Melegy, M. M. A. H., Ghoneim, M. R. Y., "The effects of sustainability disclosure on the quality of financial reports in Saudi business environment", Academy of Accounting and Financial Studies Journal, vol.23, no.5, pp.1-12,2019.

[52] LIKERT, R. A, "Technique for the Measurement of Attitudes”. Archives of Psychology, v. 140, pp. 1-55, 1932

[53] Willits, F. K Theodori, G. L., Luloff, A. E. "Another look at Likert scales". Journal of Rural Social Sciences, vol. 31, no 3, pp. 1-14, 2016

[54] Dornier, P., "Investigating the impact of comprehensive information systems on accounting information quality", Electronic Business Journal, vol.17, no.12, pp.1-15, 2018, https://doi.org/10.1108/JKM-08-2017-0371

[55] Cepêda, C. L. M., Monteiro, A. P., “A percepção dos contabilistas sobre a utilidade da informação financeira na tomada de decisão - Um estudo em Portugal", Revista Brasileira de Gestão de Negócios, vol.22, no.2, pp.363-380, 2020, https://doi.org/10.7819/rbgn.v22i2.4050.

[56] Montenegro, T. M., Rodrigues, L. L., "Determinents of the Attitudes of Portuguese Accounting and Professionels Towards Management", Journal of Academic Ethics, pp.301-332, 2020.

[57] Hoe, S. L., "Issues and procedures in adopting structural", Journal of Applied Quantitative Methods, vol.3, no.1, pp.7683,2008

[58] Wang, J., Wang, X., "Structural Equation Modeling: Applications Using Mplus", Second Edition, 2020, https://books.google.com.br/books?hl=pt-

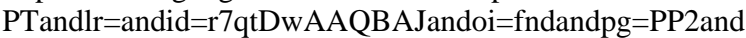
$\mathrm{dq}=$ Structural+Equation+Modellingandots $=\mathrm{wfx} 224 \mathrm{TBj} 1 \mathrm{an}$ $\mathrm{dsig}=$ T7lyOFEye0-

8JWWNuxiLx2J7ap0\#v=onepageandqandf=false

[59] Byrne, B., "Structural Equation Modeling with LISREL, PRELIS, and SIMPLIS", Basic Concepts, Applications and Programming, Lawrence Erlbaum Associates, Mahwah, NJ, 1998

[60] Ainur, "A. K., Sayang, M. D., Jannoo, Z., Yap, B. W., "Sample size and non-normality effects on goodness of fit measures in structural equation models", Pertanika Journal of Science and Technology, vol.25, no.2, pp.575-586, 2017.

[61] Diamantopoulos, A., Siguaw, J.A., "Introducing LISREL", Sage Publications, London, 2000.

[62] Marôco, J., “Análise de Equações Estruturais - Fundamentos teóricos, Software e Aplicações”. Report Number, 2010.

[63] Garver, M.S., Mentzer, J.T., "Logistics research methods: employing structural equation modeling to test for construct validity", Journal of Business Logistics, vol. 20, no.1, pp. 3357,1999 .

[64] Fornell, C. Larcker, D., "Evaluating structural equation models with unobserved variables and measurement error", Journal of Marketing Research, vol.18, no.1, pp. 39-50, 1981, 
https://doi.org/10.1177/002224378101800104

[65] Bagozzi, R.P., Yi, Y., "On the evaluation of structural equation models", Journal of the Academy of Marketing Science, vol. 16, no. 1, pp. 74-94, 1998, https://doi.org/10.1007/BF02723327

[66] INE, "Constituição e dissolução de pessoas coletivas e entidades equiparadas (N.o)" por Localização geográfica
(NUTS - 2013) e Atividade económica (CAE Rev. 3); Mensal, 2020, https://www.ine.pt/xportal/xmain?xpid=INE \&xpgid=ine_indicadores\&contecto $=$ pi\&indOcorrCod $=0008$ $067 \&$ selTab $=$ tab0 visualizada a 11 de junho 2020

[67] Etikan, I., Musa, S. A., Alkassim, R. S., "Comparison of convenience sampling and purposive sampling", American Journal of Theoretical and Applied Statistics, vol.5, no.1, pp.1-4, 2016. 